\title{
Finales para Aluna, de Selnich Vivas Hurtado: decapitación, máscaras y el polvo ínfimo del cuerpo amazónico*
}

Fecha de recepción: 17 de junio de 2017

Fecha de aprobación: 09 de septiembre de 2017

\section{Resumen}

El pensamiento intelectual aborigen representado en la novelística latinoamericana, funge como alternativa anticolonial para repensar los estados hegemónicos que intentan subyugar las culturas nacionales. En tal óptica, con este artículo propongo interpretar la novela Finales para Aluna (2013) de Selnich Vivas a través de diversas categorías de análisis que posibilitan comprender su contenido amazónico y resaltar su importancia dentro de las narrativas contemporáneas.

Palabras clave: amazónico, cuerpo, fragmentación, cultura, Aluna.

Citar: Uscátegui Narváez. A . (julio-diciembre de 2017). Finales para Aluna, de Selnich Vivas Hurtado: decapitación, máscaras y el polvo ínfimo del cuerpo amazónico. La Palabra, (31), 227-242. doi: https://doi.org/10.19053/01218530. n31.2017.7269.

\begin{abstract}
Alexis Uscátegui Narváez
Docente e investigador de la Universidad Mariana. Magíster en Etnoliteratura, Universidad de Nariño. PhD en Literatura Latinoamericana/UniversidadAndina Simón Bolívar-Ecuador. auscategui@umariana.edu.co

* Artículo producto de la investigación profesoral: "Alternativas escripturales amazónicas en El corazón de la América virgen (1924) de Julio Quiñones y El paraíso del diablo (1966) de Alberto Montezuma Hurtado"; investigación financiada y llevada a cabo en la Universidad Mariana de Colombia.
\end{abstract}




\section{la palabra}

\section{Finales para Aluna [Endings for Aluna] by Selnich Vivas Hurtado: Decapitation, Masks and the dust of the Amazonian Body}

\section{Abstract}

The indigenous intellectual thought represented in Latin American novels operates as an anticolonial alternative to rethink the hegemonic States that attempt to subjugate national cultures. In this horizon, this article seeks to interpret the novel Finales para Aluna (2013) by Selnich Vivas, through different categories of analysis that enable us to understand its Amazonian content and highlight its importance in contemporary narrative.

Key words: Amazonian, body, fragmentation, culture, Aluna.

\section{Finales para Aluna [Des fins pour Aluna] de Selnich Vivas Hurtado: la décapitation, les masques et la poudre infime du corps amazonien}

\section{Résumé}

La pensé intellectuelle aborigène représentée dans le roman latino-américain, s'érige comme une option anticoloniale pour repenser les états hégémoniques qui essayent de soumettre les cultures nationales. Nous proposons, ainsi, interpréter le roman Finales para Aluna (2013) de Selnich Vivas à partir de diverses catégories d'analyse qui permettent de comprendre son contenu amazonien et mettre en valeur son importance dans la littérature contemporaine.

Mots-clés: amazonien, corps, fragmentation, culture, Aluna 
"Ninguna escritura nos exime del delito. Semilla es de las decapitaciones"

(Sveta, 2008, p. 3)

\section{Estado de la cuestión}

La representación indígena en la historia de la literatura latinoamericana ha sido porosa, ha existido la urgencia por reconocer la heterogeneidad cultural, sin embargo, parece ser que la mirada exotista no desampara aquellos registros, en busca del esteticismo que legitima sus valores literarios. Por eso, ha sido necesario que se manifiesten otras literaturas que puedan hablar desde su propio lugar de enunciación, y que no fuese únicamente el foráneo quien pudiera recrear la dinámica de esta esfera nativa. De hecho, Cornejo (1984) señaló sobre dicho objeto del indigenismo, "que no se limitara a definirlo por su referente (el mundo indígena) y por su intencionalidad (una literatura de denuncia y reivindicación), sino que pudiera observar prioritariamente su proceso de producción" (p. 550); es decir, también validar el aporte tribal en la reconfiguración de las literaturas nacionales.
Análogamente, a inicios del siglo XX, Mariátegui (2007) legó como antecedente de estudio la noción de indigenismo, para decir que la literatura en Perú, "tiene fundamentalmente el sentido de una reivindicación de lo autóctono" (p. 281); es decir, una tendencia ideológica que revalora la cultura del nativo, puesto que "el problema indígena, tan presente en la política, la economía y la sociología no puede estar ausente de la literatura y del arte" (p. 227). Por lo tanto, al hablar sobre la corriente neoindigenista, nos estamos refiriendo a un conjunto de propuestas estético-literarias que vindican, ante todo, los acervos particulares de un espacio de representación aborigen, a sus características ancestrales, sus tradiciones simbólicas, y a sus formas de ver y entender el mundo en una suerte de política cultural que reafirma el carácter heterogéneo de la literatura latinoamericana". "En 1971, el peruano Tomás Escajadillo introdujo el término neoidige- nismo en el estudio crítico de la literatura de tema indígena" (Orrego, 2014, p. 30), para incorporar dentro de las historias de las literaturas latinoamericanas, la situación real de la vida y el pensamiento indígena, "ciertamente las diferencias tan saltantes que existen entre «sus» diversos mundos andinos nos hablan elocuentemente de la mutación, de la evolución de ese «indigenismo»" (Escajadi1lo, 1994, p. 124).

Dicha inserción de los anteriores términos en los estudios literarios, permitió a Cornejo (1984) caracterizar la novelística latinoamericana, teniendo en cuenta elementos como: el empleo de la perspectiva del realismo mágico, que permite revelar las dimensiones míticas del universo indígena sin aislarlas de la realidad, con lo que obtiene imágenes más profundas y certeras de ese universo; la ampliación, complejización y perfeccionamiento del arsenal técnico de la narrativa mediante un pro-

Esto nos permite hacer importantes distinciones al investigar sobre la representación de lo indígena, así como de lo afro y lo mestizo, en literatura latinoamericana. Propuestas como "Cabeza vestida de noche: imaginario del mal y decapitación en Fiesta en la madriguera de Juan Pablo Villalobos" (Vanegas, 2016), "Profanar cuerpos/profanar naciones: acerca de La emancipada como novela fundacional de la literatura ecuatoriana" (Marín Lara, 2016) y "La diáspora del pensamiento filosófico africano en Changó el gran putas" (Sierra Díaz, 2016) comparten esta perspectiva, al hacer la transposición estética de prácticas indígenas, mestizas en el segundo caso y africanas en el tercero, como modos de pensar sobre la violencia latinoamericana. En contraste, investigaciones como "Los Cuicatl de Acomiztli Netzahuacoyotl..." (Ortiz Caraballo, 2016) optan por hacer una arqueología de las literaturas indígenas del pasado, esforzándose por caracterizar la diferencia del concepto de literatura de estos pueblos como una práctica ritual, ética y política inserta en la cotidianidad. Por otra parte, "Definiciones y aproximaciones teóricas al género de literatura de viajes" (González Otero, 2016) propone el género de literatura de viajes como un lugar importante para observar los contrastantes lugares de enunciación y los juegos de poder desde los cuales se ha representado la identidad latinoamericana. 
ceso de experimentación que supera los logros alcanzados en este aspecto por el indigenismo ortodoxo y el crecimiento del espacio de la representación narrativa, en consonancia con las transformaciones reales de la problemática indígena, cada vez menos independiente de lo que sucede a la sociedad nacional como conjunto (p. 549).

Así las cosas, Antonio Cornejo propuso la categoría de "heterogeneidad literaria", concepción que posteriormente se convirtió en una de las teorías más inquietantes para los estudios literarios, extrapolándose a nivel latinoamericano, puesto que cada país sustentaba disímiles características que permitían irrumpir la homogenización cultural expuesta por los esteticismos nacionales; esto es, lo marginal con representaciones en "los grandes sistemas literarios, el 'culto', el 'indígena', el 'popular'; literaturas en las que se intersectan conflictivamente dos o más universos socio-culturales" (Cornejo, 2003, pp. 910).

Grosso modo, cabe agregar que la noción de novela telúrica en Colombia tuvo lugar en los primeros decenios del siglo XX. Dicha tradición, en el marco de las letras nacionales, alcanzó su mayor apogeo con la aparición de La vorágine (1924) de José Eustasio Rivera. A esta práctica narrativa, se suman otras novelas como En el corazón de la América virgen (1924), de Julio Quiñones; Toá, narraciones de caucherías (1933), de César Uribe Piedrahita; y $E l$ paraíso del diablo (1966), de Alberto Montezuma Hurtado; las cuales no han tenido mayor recensión por la crítica literaria especializada, pero merecen la misma atención que la obra de Rivera, ya que en sus contenidos se trabaja la temática indígena, especialmente lo amazónico, así como ocurre con la novela contemporánea Finales para Aluna (2013), de Selnich Vivas, la cual se ha estudiado aventuradamente desde la óptica neoindigenista. Por ejemplo, Orrego (2014) introduce la obra de Vivas dentro de lo que Escajadillo reconoce como novela neoindigenista, argumentando que en su artificio narrativo se valida la representación de un universo mítico-indígena y se prevalece un amalgamiento lírico entre el hombre y la naturaleza. Además, afirma que se vislumbra la ampliación del problema indígena al incluirse el activismo femenino y la complejización de los recursos formales; es decir, la puesta en escena de un discurso cosmovisional que suscita una voz narrativa sacra (pp. 38-44).

Sin duda, Finales para Aluna dista de la anterior clasificación literaria. Si realizamos un análisis crítico de tipo hermenéutico sobre el proyecto intercultural que entrega la novela de Vivas, podemos darnos cuenta que su artificio narrativo funge como un recurso anticolonial que puede darle mayor fisonomía a la literatura latinoamericana. Además, vislumbra un campo enunciativo no convencional en el que el espacio amazónico se traslada hacia la esfera occidental, en una suerte de tensión cultural, donde los ritos sagrados y vuelos chamánicos presentes en la diégesis, emulan una potente proyección cultural de la Amazonía. Por esta razón, quizás, su contenido no puede delimitarse a la categoría de novela indigenista o neoindigenista que Mariátegui y Escajadillo propusieron como corrientes literarias durante el siglo $\mathrm{XX}$, porque a pesar de que la novela de Vivas vislumbra rasgos especiales como la reivindicación del espacio indígena, su contenido también rebosa los orígenes de los proyectos nacionales, aquellos que no reconocen el pensamiento intelectual amazónico como alternativa de Estado, sino más bien promoviendo diversas problemáticas de repudio, desprendimiento, impugnación, exclusión y reducción cultural. Actúa, además, en una función de historia nacional como contradicción de la homogenización social; en términos de Bhabha (2010), haría parte de "las contranarrativas de la nación, que continuamente evocan y borran sus fronteras totalizadoras -tanto reales como conceptuales-" (p. 396). 
Considerar esta propuesta como una novela anticolonial y, sobre todo, como un valioso aporte etnográfico-amazónico dentro de la tradición literaria colombiana, nos obliga a revisar y analizar otros aspectos paratextuales. En uno de los primeros estudios sobre esta novela, encontramos la reseña de Lima (2013), en la que señala que la novela de Vivas lega a la literatura colombiana un sentido de comparecencia para revalorar la dignidad humana:

Muito mais que simples conflitos políticos e sociais, a narrativa de Selnich Vivas Hurtado presenteia a literatura latino-americana com uma história viva e forte onde o cotidiano e as relações precisam ser repensados, resguardando, sobre tudo, o respeito à dignidade humana. É uma boa oportunidade de leitura para refletir o nosso contexto nesses dias de raros sentimentos de alteridade (p. 184).

Acto seguido, Jiménez (2014) considera Finales para Aluna como una obra de la "incertidumbre", en el sentido de que su narrativa ostenta innumerables simbolismos, generando que su artificio no se enmarque en una sola categorización: "la gran paradoja en la que nos sume Vivas es que con novelas como esta quizás debamos incurrir en el vicio academicista de inventar un nuevo género literario, que nos permita hablar de todas estas obras que hacen del vacío su contenido" (p. 135). Por su parte, Rodríguez (2013) señala que Finales para Aluna posee un formato de novela corta y, tal como nos indica el crítico, es «una novela alemana con aliento de selva»" (p. 215). La novela de Vivas, sin duda, encaja muy bien en esta categoría (noción que más nos interesa desarrollar en este trabajo); porque gran parte de su novela es amazónica, no tanto por territorialización, sino por la potencia metafórica que desarrolla su contenido a lo largo de la historia, pues en sus páginas se destaca la interacción metafísica entre naturaleza $\mathrm{y}$ cultura.

Entre otros aspectos, la novela es una apuesta por vindicar otro tipo de pensamiento intelectual, la sabiduría ancestral que surge a través de la intercomunicación con plantas maestras, como la yera (tabaco), el jibie (coca) y la una uai (yagé). De esta manera, la obra se constituye dentro de otras esferas referenciales, esto es, el espacio amazónico que funge como lugar de enunciación y latencia cultural dentro del mundo europeo. Por eso, la novela de Vivas desde su heterodiscurso narrativo, establece otras formas de representar la selva; es una narrativa anticolonialista que desvirtúa el progreso de las multinacionales en América Latina durante el siglo XXI. En la romance encontramos una tensión cultural que implicaría trabajar las dominaciones de representación, reflexionando posibles categorías, como: la decapitación, las máscaras y el polvo ínfimo del cuerpo amazónico, que ayudarían a comprender cómo el cuerpo amazónico está sometido a brutales mecanismos de dominación, pero que también dicho estado corpóreo cuenta con intensas líneas de fuga que ayudan a mantener su existencia, para ello es fundamental recurrir a la categoría del cuerpo sin órganos (CSO) propuesta por Deleuze y Guattari (2002), dicho postulado admite agenciar en la novela, la liberación del cuerpo mediante el empleo de plantas maestras, tal y como lo experimentó Antonin Artaud con el peyote en México, donde "el cacto sagrado le permitió dejar su cuerpo pútrido por el opio e introducirse dentro de una experiencia ascética, que a su vez le asintió dejar su mundo occidental y aprender del mundo ancestral de los Tarahumaras" (Uscátegui, 2017, p. 98); así como sucede con la personaje Aluna, que no solo se despoja de sus órganos, sino también se libera de la opresión europea por medio del vuelo chamánico.

En la novela de Vivas, encontramos que a través de las personajes que representan a una determinada nacionalidad, las europeas por ejemplo, intentan minimizar a la cultura nativa en 
una especie de grilla biopolítica; pues la scalp de la protagonista, alegoriza la decapitación de la cultura amazónica, lo abyecto para la cultura occidental. Para tal logro, el postulado de Deleuze (2009) ayudará a comprender que el cuerpo también se torna materia política, siempre está en constante lucha ante la dominación, por tanto, funge como un campo trascendental, en el sentido en que es siempre inmanente, es decir, puede fragmentarse como en el caso de Aluna, pero siempre permanecerá latente, incluso de forma virtual.

De esta manera, se puede decir que Finales para Aluna es una novela que invita a repensar el esteticismo literario, pues su autor de una manera sugestiva, trasporta el espacio selvático y toda su imaginería amazónica hacia el mundo académico en Alemania, lo que implicaría analizar detenidamente su gran densidad etnográfica, pues se puede apreciar en varios parajes narrativos, gran parte del pensamiento ancestral de la cultura indígena minika, comunidad que aún habita en el río Igaraparaná en la Amazonía colombiana. Además, la novela de Vivas se puede leer como una posibilidad transgénero que desvirtúa la idea de que la selva está homogeneizada por una sola tendencia sexual, sino también desde lo amazónico se puede reflexionar la diversidad, pues como bien expresa Butler
(2007), "el género se construye culturalmente" (p. 54).

En Finales para Aluna, se recrea la historia de una nativa lésbica, que en el desarrollo de la diégesis, se presenta a través de un heterónimo que le permite desempeñar diferentes roles, Rita Feind (cristiano), Sveta Aluna (literario) y Nimairango (espiritual o chamánico). Esta lideresa indigenista fue aparentemente raptada en la ciudad de Freiburg en Alemania, por ir en contra del sistema capitalista que se encarga de explotar la tierra sagrada de la Amazonía, pero, lo que realmente se ve a lo largo de la narración es que su cuerpo fue desmembrado por su amante Barbara Ehinger, rectora de la Universidad de Freiburg, quien además la decapitó dejando como trofeo tan solo su cuero cabelludo (scalp). Más adelante, se suscita algo insólito para la cultura europea, pues se realiza en la Catedral de Freiburg la primera minga amazónica en la historia alemana, donde las participantes feministas proclaman la liberación de Rita. No obstante, por intereses políticos y para no desatar una guerra diplomática entre Alemania y los movimientos aborígenes de América Latina, la canciller Angela Merkel, decide conjuntamente con las victimarias del crimen suplantar a Aluna con una vietnamita de similar apariencia física, quien utiliza la scalp de Nimairango para mitigar la protesta, devolviendo la tranquilidad en la ciudad de Friburgo.

Con la anterior línea argumental sobre la novela de Vivas, son múltiples las entradas para encontrar un diálogo crítico, pues el solo hecho de hallar una representación nativa-lésbica en la narración, ya es una interpelación hacia la cultura homogénea que se presenta en Alemania. Asimismo, realizar un rito en medio de la Catedral de Freiburg, también es una trasgresión a la norma católica de Europa. De este modo, en la novela de Vivas hay una suerte de cuerpo extraño, porque, en un primer momento, no se define su identidad, ¿europea o amazónica? En segundo lugar, el tipo de cuerpo que se re-crea en Finales para Aluna, es un cuerpo sin órganos (fragmentación del ser), en el cual Aluna alcanza el punto supremo de su existencia cuando logra la desorganización de sus entrañas a través de la intercomunicación chamánica admitida por el empleo de plantas sagradas.

\section{Decapitación del pensamiento amazónico}

En la novela de Vivas, encontramos un secuestro simulado, aparentemente Los Ángeles de la Civilización (grupo paramilitar) son los que quieren eliminar a Sveta, pero, es la Rectora de la Universidad de Freiburg quien la despedazó en su propio cuarto de estudio por razones 
de celos, fruto de un triángulo amoroso-lésbico, "el scalp se puede quedar como trofeo del amor colectivo; pero el resto del cuerpo debe desaparecer definitivamente y lo antes posible. No me importa que lo tengamos que quemar" (Vivas, 2013, p. 42). De esta manera, se supone un falso secuestro político con la indigenista quien estaba en contra de las multinacionales más poderosas del planeta, aquellas que en varias ocasiones amenazaron con aniquilarla, "-no tenemos tiempo; la van a obligar a hacer huelga de hambre, pues se negará a comer en cautiverio. -O la van a trozar" (Vivas, 2013, p. 18); por esta razón, la rectora inventará un plan que le permita enmascarar la muerte de su amada Aluna.

Bárbara, luego de fragmentar el cuerpo de Sveta, recordó el afecto que sentía por ella, su amor había nacido por atracción intelectual, "mi Aluna era más la fuerza en el pensar que la belleza exótica. Menos la mujer diminuta y más el poder que me imantaba. Esa mezcla de anarquismo eslavo y de beligerancia indígena" (Vivas, 2013, p.18). De alguna manera, esta podría ser una de las razones por las que desea conservar su scalp como trofeo con el fin de eternizar su sabiduría aborigen, sin duda una reliquia que simbolizaría el triunfo del pensamiento europeo sobre el nativo. No obstante, el cuero cabelludo también representa el conocimiento ancestral de la cultura amazónica, aquel que la protagonista va a regresar a través de un rafue (vuelo chamánico) para recuperar su identidad, porque el rol de Rita Feind gira en torno a múltiples identidades y máscaras. Su carácter amazónico es meramente espiritual, aunque sus genes provienen de una madre checa alemana de Bohemia y de un padre nativo de la Sierra Nevada de Santa Marta, quienes se conocieron en Praga en un Encuentro de Juventudes comunistas. Esto le permite, de algún modo, ser una mujer militante de las culturas indígenas suramericanas, defendiéndolas frente a aquellos mecanismos europeos que intentan reducirlas o aniquilarlas, "a Sveta Aluna se la llevaron para acallar nuestras voces, para silenciar y ocultar los crímenes de la multinacional germano-china Kulturerde, para negar los derechos ancestrales a la felicidad de los pueblos más antiguos de América" (Vivas, 2013, p. 24). De este modo, Aluna en vida, fue una mujer que transmitió con sus cantos otras formas alternativas de concebir el mundo, enseñando en la academia occiden- tal que aún prevalecen formas ejemplares de pensar y vivir en armonía con la madre natura.

En esta perspectiva, la desaparición del cuerpo de Nimairango, representa la aniquilación del pensamiento amazónico, puesto que al suplantarse un secuestro político por un crimen pasional, Barbara Ehinger y sus cómplices Polinka y Nadjenka, intentarán borrar su existencia a como dé lugar. Por tanto, la rectora realiza una especie de tzantza occidental, en el caso de los amazónicos shuares ${ }^{12}$ reducen la cabeza del enemigo y la guardan como trofeo e incluso como objeto intimidante para las futuras guerras entre clanes, pero en este caso hay una decapitación, donde solo se conserva el cuero cabelludo de la protagonista como adorno de museo. De igual forma, en el trascurso de la novela, se puede observar que el discurso también es una herramienta utilizada por la rectora para fragmentar el cuerpo de Aluna. Dicha hipótesis se puede validar cuando la profesora Sonia Herz, en un correo electrónico, reclama el maltrato generado hacia Nimairango:

Usted la destruye con ataques horribles a su autoestima, usted la corta en pedacitos con sus resenti-

2 En la novela Las tres mitades de Ino Moxo y otros brujos de la Amazonía (1981), del escritor peruano César Calvo, se puede apreciar cómo los mal llamados jíbaros realizan adecuadamente la fórmula sagrada para reducir las cabezas de sus enemigos. Entre líneas, se describe: "Un guerrero jíbaro tiene derecho únicamente a reducir la cabeza del contendor que él mismo ha dado muerte peleando, que él supo vencer de igual a igual enfrentándolo sin ventaja ni emboscada, previo anuncio de guerra y con armas idénticas" (p. 192). 
mientos viscerales. Usted tiene una forma tan venenosa de tratar a los seres que la aman que una palabra suya basta para hacerlos migajas.

[...] Usted se aprovechó de su sed intelectual, de su deseo de cambiar el mundo, para volverla esclava de la cama. Usted ya no la amaba; apenas la citaba para insultarla y degradarla. Ahora se la ve fracasada, desganada, sin energía interior. Por momentos parece disecada, muda, lerda. Ella se siente un montón de huesos, incapaz de pensar, cantar, danzar y escribir (Vivas, 2013, pp. 85-86).

A través de este fragmento y a lo largo de la narración, se puede observar que el cuerpo de Aluna es aniquilado en todo sentido, si bien las manos de la rectora son un mecanismo de violencia en extremo, el discurso de la amante también es un medio por el cual se puede reprimir el carácter intelectual y cultural de la protagonista. Por esta razón, el cuerpo de Nimairango es un cuerpo fragmentado, porque hay una pérdida evidente de sus miembros corporales que le impide ser una mujer compacta, este supuesto en palabras de Deleuze y Guattari (2002) podría entenderse como un cuerpo vaciado (p. 156).

\section{Máscaras y sus límites de re- presentación}

En Finales para Aluna, no se puede prescindir el lugar de enunciación del autor, pues dentro de su experiencia amazónica, Selnich Vivas ${ }^{23}$ ha comparecido de la sabiduría ancestral de los minika para vindicar la cosmovisión amazónica en su novela, aquella que ha sido reducida en diversos sentidos de representación por la cultura hegemónica de occidente. Es más, el propio autor explica cómo la protagonista de su novela, luego de ser fragmentada, logra a través de las plantas sagradas, el canto y la danza, un rafue; es decir, un modelo -alternativo de conocimiento- que le permite alcanzar la intercomunicación con el mundo selvático:
¿Cómo se estimula el vuelo chamánico en el caso de Sveta Aluna? Existen múltiples maneras de provocar el estado alterado de la conciencia y no todas ellas, como se suele creer, están asociadas a sustancias enteógenas. El trastocar de los sentidos en el caso de Sveta Aluna se produce por una impostación, por máscaras, por préstamos y robos estéticos.

Me explico: Sveta Aluna me permite una forma del travestismo; suelo creer que soy y puedo hablar y escribir como una mujer que ha vivido y amado en alemán, español y dos lenguas indígenas: el minika y el magü tagü. En tal sentido realizo mi muerte verdadera. Doy muerte a todo lo evidente y me reinvento en cada poema. Simulo su voz y me embriago con sus historias. Sveta es una colección de máscaras que necesito para aliviar mis dolencias y transitar de vez en cuando entre los

3 La formación académicamente recibida en Alemania, le ha permitió conocer más sobre las culturas indígenas de su país, lo que motivó de similar forma, a introducirse por varios años en la selva amazónica de Colombia para aprender la lengua y las tradiciones ancestrales de los nativos minika del río Igaraparaná. Selnich Vivas es escritor, editor y profesor de Literatura del Grupo de Estudios de Literatura y Cultura Intelectual Latinoamericana (GELCIL), de la Universidad de Antioquia. Doctor en Literaturas alemanas y latinoamericanas de la Universidad de Freiburg, Alemania. Estudió lengua y literaturas alemanas en la Universidad de Innsbruck, Austria, y literatura en la Universidad Nacional de Colombia, sede Bogotá. Entre sus obras, se encuentran: Komuya uia: poética ancestral contemporánea (Ensayos, 2015), Utopías móviles (Ensayos, Diente de León, 2014), Contra editores (Cuentos, Unalula, 2014), Finales para Aluna (Novela, 2013, Ediciones B), Zweistimmige Gedichte (poemas en colaboración con Judith Schifferle, Prut Verlag, 2012), Déjanos encontrar las palabras (poemas sobre Paul Celan e Ingeborg Bachmann, Premio Nacional de Poesía, Universidad de Antioquia, 2011), Sveta Aluna. Stolpersteine _poemas tráspies (El Astillero, 2008), K. migriert (en torno a la obra de Franz Kafka y Colombia, Universität Freiburg, 2007, online) y Para que se prolonguen tus días (novela, El Astillero, 1998). 
delincuentes que gobiernan esta sociedad. Ella es otra forma de pensar y de sentir este país, sin la cual no podría resistir la violencia vuelta espectáculo (Vivas, 2015, p. 66).

El anterior fragmento, ayuda a comprender el sentido atávico en la novela de Vivas, pues si bien la visión enteógena en la que se apoya el autor, ayuda a ocultar su identidad a través de múltiples máscaras, a su vez, funcionan como alternativas que permiten a la voz narrativa aparentar nuevas identidades culturales-europeas; esto explicaría los significados que presenta el heterónimo de la protagonista: Rita Feind en alemán significaría "enemiga", aquella que a lo largo de la narración representa lo antagónico en la cultura occidental; Sveta Aluna, siguiendo a Manuela Fischer y Theodor Konrad Preuss, [/aluna/], que en la sabiduría de los Mamas de la cultura Kágaba de la Sierra Nevada, hace referencia a "pensamiento", "recuerdo" o "sentimiento"; es decir, representa la madre de los lagos de $\mathrm{sal}^{34}$ (1993, p. 143); por su parte, Nimairango comparte la simbología amazónica de los minika, aquella representación intelectual y espiritual que se mantiene latente en Alemania.

Por otra parte, se puede distinguir que la protagonista de la novela representa la lucha de la cultura amazónica, aquella que está siendo subyugada por el régimen occidental. Por lo tanto, en la novela se establece una especie de kulturbegründer, esto es, aquellos mecanismos de poder que se encargan de hacer la verdadera cultura, por ejemplo: "los Ángeles de la Civilización se la llevaron. La multinacional de la Kulturerde no quiere suspender la explotación de yacimientos petrolíferos en los territorios sagrados de los hermanos indígenas. Por eso quieren atemorizar a mi Sveta o, peor aún, la quieren eliminar" (Vivas, 2013, p. 14). De esta manera, se puede establecer que Los Ángeles de la Civilización, más que un grupo paramilitar al servicio de las multinacionales germano-chinas, son los que controlan la cultura menor que, en este caso, son los nativos; sin embargo, el pavor que tiene esta agrupación es que Nimairango podría acabar con sus explotaciones lo que permitiría eximir a sus coterráneos indígenas de aquel capitalismo:

Me ha dicho la profesora doctora Herz, actual directora del Romanisches Seminar, que es hora de cambiar la perspectiva colonialista de nuestra universidad. Y con razón. ¿Qué universidad se puede sentir digna de su función y de su origen si se pone al servicio de los megaproyectos expansionistas sobre otros continentes y culturas? ¿Qué universidad se puede sentir digna de su función si se presta al servicio del embrutecimiento científico y la reducción de lo humano? La nuestra no es la excepción. Los estudios de la Romanística, por ejemplo, siguen suponiendo que América Latina no es otra cosa que un apéndice de Europa y suelen creer que lo único valioso en ese continente es la continuación de la cultura europea, para así facilitar el neocolonialismo global. Se deja de lado el estudio de las lenguas nativas $\mathrm{y}$ se promueve la expansión del pensamiento occidental. Estudiar los cientos de lenguas vivas de ese continente significaría, y aquí cito a Nimairango darles el reconocimiento político a los pueblos que las hablan, es decir, el legítimo derecho a defender sus culturas, su modo de vida, su visión de mundo. Lo que a la postre obligaría a las multinacionales a salir de los territorios sagrados de los indígenas. [...] $\mathrm{Si}$ el mundo aceptara la palabra ancestral, los pueblos más antiguos de América lograrían detener el avan-

$4 \quad$ Ver mito Kogi: “La sal” de Alfonso Auigi (Noavaka) recopilado por Fischer y Theodor Konrad Preus, 1993, pp. 143-144. 
ce del capitalismo salvaje (Vivas, 2013, pp. 24-25).

Como se puede observar anteriormente, la novela de Vivas es muy sugerente en cuanto a la suprarrepresentación cultural, "en la cual una voluntad de presencia integral se da al espectáculo del aniquilamiento de la posibilidad representativa misma" (Nancy, 2006, pp. 20-21). La cultura hegemónica de occidente representada en la rectora y demás sistemas capitalistas, buscan exterminar la cultura menor que, en este caso, es la amazónica representada en Aluna, pues como dice JeanLuc Nancy (2006), exterminio "es ir al extremo, no dejar que nada subsista" (p. 11). No obstante, en la narración hay una interpelación ante dichos mecanismos de civilización empleados en el intento por reducir la cultura nativa, "yo soy tu verdadera Alunochka, la que te dará la estocada final y te cortará en pedacitos y los exhibirá en el museo de la universidad, con el fin de demostrar que a mayor humanismo, mayor brutalidad de la civilización europea. Los periódicos dirán: Escritora, doctora en literatura y asesina de profesoras" (Vivas, 2013, p. 58).

Igualmente, Vivas en su novela revive los valores epistémicos del mundo selvático, pues el conocimiento impartido desde este hito, es una alternativa que permite acceder a diversos es- pacios de confrontación con la cultura nacional, como un valor más para hacer kulturbegründer y no estigmatizarlo en la noción de que destruye la cultura pura (kulturzerstörer), sino la consolida y la diversifica. Por tal razón, Vivas no olvida la simbología del cuerpo amazónico, en la cual, refuta la supremacía cultural de occidente que intenta borrar la representación de la cultura alternativa que se enuncia desde la selva. Por ello, el autor de Finales para Aluna reconstituye la posibilidad de que el conocimiento ancestral sirve como un medio alterno para generar hermandad entre la humanidad occidental y el mundo amazónico; además, increpará aquella nacionalidad que busca expandir el pensamiento occidental en busca de la reducción de la intelectualidad amerindia. Por ejemplo, veamos el siguiente caso de la protagonista:

Esta diminuta mujer de tez oscura y cabello largo, lacio y negro brillante, padeció aquí y allá del Atlántico el racismo acendrado en contra de nuestros hermanos indígenas y en contra de los modelos alternativos del conocimiento. Por eso desde muy niña se convirtió en una de las defensoras de los derechos humanos de los pueblos ancestrales y luchó con discursos contundentes, fundados en el conocimiento de la historia y la investigación empírica, por reparación cultural y económica justas. Luchó por la devolución de las tierras sagradas de sus ancestros los kankuamo, hoy día aniquilados; luchó por la educación propia y la defensa del idioma y las tradiciones poéticas de los minika, hoy reducidos por el cristianismo y el alcohol. En ambos casos se enfrentó a un enemigo muy poderoso: el capital transnacional dispuesto a globalizar el planeta con formas de vida absolutamente deshumanizadas que han transformado no solo a los indígenas sino a la casi totalidad de los habitantes de la Tierra en esclavos del dinero y del consumismo. La esclavitud y el colonialismo no han terminado en el mundo. En América Latina no cesa la invasión del bárbaro europeo y de sus máquinas buscadoras de petróleo y de oro (Vivas, 2013, pp. 23-24).

Con lo anterior y retomando la posibilidad de construir una cultura diferente a partir del conocimiento alternativo que comparte la selva más allá de lo occidental, en la novela de Vivas, también se ve enfáticamente la venganza por parte de la cultura minoritaria representada en Aluna hacia la cultura superior de su examante, queen 
varias ocasiones la redujo hasta el borde del exterminio, "he sido torturada y violada por ser indigenista, he sido incinerada por ser europea, pero nada me duele tanto como tu forma de humillarme por ser una mujer pobre, fea y bruta. Rectorcita, ahora viene mi venganza: destruiré tu cultura libresca en un viaje" (Vivas, 2013, p. 54). Si bien es cierto que la novela entre capítulos enuncia cómo la cultura superior europea intenta avasallar y destruir la minoritaria por diferentes intereses políticos, capitalistas y sentimentales, la noción de kulturbegründer (fundador de civilizaciones) también es válida para el espacio amazónico, por tanto hay una suerte de desquite por parte de la cultura minoritaria a través del rafue y las plantas sagradas, con el fin de liberar a Aluna del supuesto secuestro y la opresión occidental:

Durante toda la noche y hasta el amanecer los dos grupos alternarán su participación con un repertorio muy variado de cantos. Se convocará al sol, al agua, a la planta de coca, a la de tabaco, a las abejorras, a las hormigas, al chontaduro y a la albahaca, para pedir por la libertad de Rita Feind. A media noche se hará un conjuro en el que Finorango y Anirango beberán, mezcladas con kaschirí, las cenizas del cráneo de Nimairan- go, la mujer de la sabiduría. Menschlicher Fraunenkopf, recordaré uno de sus versos: Cabeza humana de mujer. El cráneo habrá sido quemado, pilado y cernido hasta volverse un polvo fino que yo misma mezclaré con la bebida. Depositar una manotada de polvo de Nimairango en el kaschirí será una labor de rutina, una pizca de azúcar más para afinar el sabor. Las manifestaciones prometerán al mundo, entre sorbos de kaschirí, devolverá la libertad y la vida a Nimairango (Vivas, 2013, pp. 76-77).

El transitar de un lugar a otro entre el mundo occidental y amazónico, impide que Aluna pueda mantener su identidad natural, por ello se justifica el uso ambivalente de las máscaras. Según la voz narrativa, la protagonista defraudó la ideología cultural de sus progenitores, pues ambos le habían enseñado inconscientemente a repudiar Europa y a defender América, "no será capaz de vivir como una india en el Amazonas ni como una centroeuropea en Alemania. Le costará desprenderse de sus lujos burgueses hippies y ecologistas, le costará dejar los libros, el computador, el celular. Se hará indigenista por trabajo, por arrogancia y vanidad, para escandalizar a los europeos con su polvo verde y su pasta de tabaco, con sus viajes de vómito y diarrea entre espasmos de yagé" (Vivas, 2013, p. 60). Asimismo, Barbara por medio de un email dirigido a su examante Sonia Herz, expresa su repudio hacia Aluna por sus conductas ambiguas:

Yo la conozco y sé que es parte de sus juegos de roles: una vez se siente más europea y otra vez más indígena. Un día ama como una mujer y al otro como un hombre. Defiende y ama la literatura, pero propone la quema de libros. $\mathrm{Su}$ mística le sirve para cantar los ruakiai de los minika y para atacar a los hombres que subordinan a la mujer. Ella no puede actuar de otra manera. Ella quería que yo la olvidara y al mismo tiempo la buscara, que la aborreciera con amor.

[...] Rita es una persona de muchas caras y cientos de máscaras ridículas. En cada lengua que estudia multiplica máscaras. (Vivas, 2013, pp. 88-91).

Con todo lo señalado arriba, se puede decir que las experiencias académicas y amorosas que ha tenido Aluna en Europa, ha generado que su cultura parezca occidental, pero, su poderío amazónico está impregnado en su ciclo menstrual que se reconstituye en cada luna (A-luna), que junto con las plantas sagradas, le facilitan el conoci- 
miento suficiente para transitar entre dos espacios totalmente opuestos, Alemania y la selva.

\section{El polvo ínfimo del cuerpo amazónico}

Se puede entender como polvo ínfimo del cuerpo amazónico, a la permanencia absoluta de los restos del cuerpo de Aluna, en otras palabras, sus órganos fueron fragmentados y desaparecidos, pero, su vida aún sigue latente entre los recuerdos de sus amantes; y, por supuesto, resplandece por medio del rafue en el momento en que su cuerpo entra en un estado introspectivo de meditación y búsqueda del punto supremo de la existencia humana, medio que también le permite que su espíritu aurático regrese en busca de su ínfima parte corpórea, su scalp. Siguiendo a Deleuze (2007), se podría extrapolar el polvo ínfimo con la categoría de "la inmanencia de la vida", porque se podría entender como una especie de -plétora vital-; en términos propios del filósofo francés, "la pura inmanencia es UNA VIDA y nada más. No es la inmanencia de la vida, sino que lo inmanente es en sí mismo una vida. Una vida es la inmanencia de la inmanencia, la inmanencia absoluta: es potencia, beatitud plena" (p. 37).

Ahora bien, uno de los primeros instantes donde se puede ratificar la posibilidad de que se valide el polvo ínfimo en la novela de Vivas, es a partir del momento en que la rectora expresa que a pesar de haber eliminado el cuerpo de Aluna, su imagen continuará proyectándose en una suerte de apariciones metafísicas, "para no decirles que cada día, por fin, creía librarme definitivamente de Alu, quien, sin embargo, se me aparecerá con más fuerza después de la muerte. Como si ella me soñara, me viviera y me reinara" (Vivas, 2013, p. 20). A pesar de que Nadjenka y Polinka, utilicen sahumerio para mitigar el olor del cadáver de Aluna, la vida seguirá inmanente, porque el polvo ínfimo está impregnado en la nariz y pulmones de las criminales como una espina imposible de extraer. Esto sería, de alguna manera, la beatitud amazónica, "le desollaré a mi Aluna amada la piel del cráneo. Un corte perfecto, sin echar a perder ningún cabello. La sangre y el semen convertirán mis palabras en un solo olor que jamás lograré extirpar de mis pulmones" (p. 63).

Por otra parte, el polvo ínfimo estará presente en el cuerpo de las amantes de Aluna, la rectora y la profesora de literatura. En el caso de la primera, la vida de Sveta está latente cuando recuerda los besos que se desplegaban por todo su cuerpo, en un sentido erótico, los fluidos salivales y vaginales determinan, de algún modo, la presencia indiscutible del espíritu de $\mathrm{Ni}$ mairango, que a pesar que está muerta, su vida sigue presente. Por ejemplo, Barbara imagina la siguiente escena con su víctima:

Aceptaré y empezaré a sentir su presencia retumbante, su humedad entre mis labios. "¿Todavía es una formalidad aprisionada en los principios occidentales o por fin se decidió a arrancarse de sí misma y a encarnar en mis ganas irracionales?". No habrá miedo en sus narices anchas y afiladas y se permitirá romper la distancia, la maldita racionalidad de la academia. [...] Ella será ahora la sabiduría, interrogará y sostendrá el mundo con sus palabras simples. Dispongo solo de unos instantes, diré, para probar los decibeles de su impulso. "En ese caso, desaparezco", y se esfumará a tiempo, justo antes de que Polia, Nadja y yo nos apropiemos de su cuerpo y le arranquemos el scalp (Vivas, 2013, pp. 47-48).

Para ejemplificar mucho mejor la categoría sobre polvo ínfimo, se podría traer a colación el documental Nostalgia de la luz (2010) de Patricio Guzmán, en el cual, la potencia de la vida está latente entre el ambiente desértico, al igual que el espirito de Aluna en el espacio occidental. En el caso de lo ocasionado por la dictadura chilena, los 
cuerpos desaparecidos siguen inmanentes tanto en el recuerdo de los familiares como también en la arena de Atacama, es decir, las partículas óseas de las víctimas siguen desplazándose entre el ambiente atmosférico. Además, es interesante encontrar en este filme que, mientras el observatorio astronómico que está situado en el mismo sector de los crímenes se dedica a estudiar los cuerpos celestes del espacio exterior, los familiares mantienen sus esperanzas vivas por hallar el más mínimo trozo de sus allegados en la tierra. En cuanto a la textura de una estrella que a lo lejos se ve tan brillante, a través del telescopio, se puede comprobar que dicho astro se extinguió desde hace muchos años luz, pero su brillo sigue presente para el ojo humano. Esto ilustraría la inmanencia absoluta, al igual que los restos humanos que permanecen ínfimamente extraviados en el desierto.

Lo anterior, en correlación con la novela de Vivas, a pesar de que el cuerpo de la protagonista fue fragmentado, su vida sigue latente en la scalp, esto es el polvo ínfimo de la vida amazónica, porque se reconstituye a través del vuelo chamánico y se intensifica con el recuerdo erótico del trío lésbico, "no solo invento mis fantasmas, querida Alunochka; también los alimento con tus huesos. Me odias por engañarte, pero tu amor sigue vivo aún más allá de tu muerte"
(Vivas, 2013, p. 53). De manera similar, Vivas (2008) en su poemario Stolpersteine (Poemas-Traspiés) por medio de su seudónimo Sveta Aluna, nuevamente evoca la idea de la fragmentación del cuerpo, lo cual, al igual que su novela Finales para Aluna, es una apuesta poética por mantener la presencia/ ausencia de la memoria ancestral en el mundo occidental; por ejemplo, observemos el siguiente texto:

Quién nos sostiene colgados con predilección a este plural de frustraciones?

Una coja soriasis.

Rasca,

tu

mu-

ti-

lado cuerpo.

Finos son aún tus huesos.

Tus dientes, tus días y noches, hijo,

tu bramido.

Oh Gott. (Sveta, 2008, p. 42).

En este sentido, la novela de Vivas invita a reflexionar ¿cuál podría ser la intensiva línea de fuga de Aluna, que le permite volver a sus orígenes amazónicos luego de la decapitación? En este caso, el rafue es el medio alternativo de conocimiento que le permitió alcanzar no solo la más intensa alquimia entre las plantas sagradas y su cuerpo, sino también reconocerse como indígena amazónica sin abandonar totalmente Europa:

Aunque te encueves en tu búnker, no te librarás de mí, hittlercita. [...] En mi cama, antes de las primeras luces, recordaré uno de sus versos más repetidos y convertido en grafiti en las paredes de la universidad y volveré a desear su scalp, sus huesos, sus músculos, su semen: "Keine Schrift befreit uns vom Verbrechen". Ninguna escritura nos libera del delito. Yo le enseñé la pasión por los libros y ahora Rita promueve la quema de libros. Qué horror, destruirá a Occidente si no la detengo. Si antes no la quemo con sus arengas" (Vivas, 2013, p. 54).

Además, por otro lado, se encuentra la posibilidad de liberar a Aluna del supuesto rapto cuando varias mujeres marchan por la Maria-Theresien-Straße disfrazadas de Nimairango, utilizando toda la indumentaria que simboliza el poderío amazónico y el performance dancístico que escenifica la potencia de la selva pura (Schwarzwald): "sus cuerpos reinventados de collares de dientes de jaguar, coronas de plumas de tucán y papagayos, extensores de yanchama o corteza de árbol; sus 
cuerpos tatuados para la protección y maravillosamente poblados de mensajes geométricos que exaltarán la fertilidad, la abundancia, el poder de la menstruación y la libertad de la mujer. Sus cuerpos pretenderán un único cuerpo paciente que exigirá el retorno a la vida de Rita" (Vivas, 2013, p. 65).

El rafue ${ }^{45}$ como línea de fuga, permitirá reconstituir el aura espiritual de Aluna, al llevarse a cabo en la catedral de Freiburg, tanto Finorango (profesora Sonia Herz) y Anirango (rectora Barbara Ehinger) beberán las cenizas del cráneo de Nimairango. Dicho acto ancestral es una alternativa para convocar su retorno vital, también es un jágijji, que en la tradición de los minika, significa "aliento de vida", es decir la sabiduría que se requiere para vivir en armonía en la selva. De tal manera que, utilizar plantas sagradas como la yera (tabaco), el jibie (coca) y la una uai (yagé), permiten restituir a través de una fuerza espiritual de la protagonista, en términos de Deleuze, esto sería la inmanencia de la vida. Asimismo, la potencia de la vida de Aluna está marcada en el rasgo erótico de su cuerpo y apariciones metafísicas, "Nimairango te obsequiaba la felicidad y te la arrebataba en un mismo orgasmo fuera clitoral o vaginal" (Vivas, 2013, p. 81).
A pesar de que Anirango enseñó varias lenguas a Nimairango y a pensar desde el mundo europeo, Aluna decidió liberarse de aquella farsa cultural que no le permitía ser ella misma, por tanto decidió pensar por ella misma (selbstdenken), lo que significa que tuvo la iniciativa por recurrir a otra posible línea de fuga, más aún, cuando conoció y se enamoró de la profesora Herz quien le inculcó los valores y el respeto por la diversidad, algo que no hubiera podido entender de la misma manera con su amante rectora:

Finorango fue efectivamente la primera mujer que me habló de Hannah Arendt y de Judith Butler. Gracias a estas autoras entendí que la pregunta no era por mi género o por mi rol sexual, sino por mi diversidad en el pensar. Discutir en torno a las concepciones sociales y políticas de la mujer me llevó a descubrir que yo pertenecía a unas minorías que habían sido borradas de la memoria de la humanidad. Y Finorango me animó, justamente, a sentirme indígena. Me habló del derecho que tenía de elegir una cultura, la que quisiera, las que me gustaran. Hablaba de una condición humana distinta a la programadaen
Europa. Esa fue una palabra mágica, me encantó y me enamoró.

[...] Eso me bastó para dedicarme en mi tesis doctoral al estudio de la influencia del pensamiento indígena en la literatura alemana. ¿Quién se hubiera imaginado que mi universo se trasladaría en un santiamén de la MaschaKaléko-Straße al Kótue en la selva amazónica? (Vivas, 2013, pp.100-101).

Por medio del anterior fragmento, se puede decir que otra de las líneas de fuga de Aluna es el amor como medio para reencontrarse con sus orígenes amazónicos, "Finorango me dio la fuerza para volar cada vez que necesitaba refugiarme en la selva" (p. 101), en tal sentido que, su pensar se introdujo en un dualismo epistémico entre lo occidental y la sabiduría que adquirió con los minika. Esto explica que su identidad se oculte entre máscaras y que su actitud se multiplique según sus intereses sexuales, políticos e ideológicos.

No obstante lo anterior, Aluna realiza un ruaki (rito a manera de canto) amazónico en medio de un bosque nevado de Alemania, apoyándose de las fuerzas inspiradoras de la yera, el jibie y el una logra fugarse de

${ }^{4}$ Siguiendo a Selnich Vivas (2015), "el rafue fija las reglas de educación, de comportamiento colectivo e individual y de administración de la cultura. Por eso el rafue es un kirigai o canasto del conocimiento" (p. 90). 
occidente para adentrarse en la verdadera selva junto al espacio ancestral de los minika. La sabiduría que facilitó el yagé en su cuerpo fue inefable, pues el yagé actuaba como un cuerpo extraño dentro de su ser, que le permitió alcanzar el conocimiento inminente; es decir, la línea de fuga o el vuelo chamánico que le accedía ser una-otra dentro de Europa; por tanto, "no había algo más necesario en su vida que un viaje a su interior. No quería huir de este lado del mundo, quería traer el otro lado del mundo a este" (Vivas, 2013, p. 108).

\section{Conclusiones}

El montaje de la liberación de Aluna que se suscita hacia el final de la novela, ejemplifica claramente las categorías propuestas en este acercamiento crítico. Al suplantarse el cuerpo de Aluna con el de una vietnamita de similar apariencia física, indica que hay ciertos límites miméticos, en el sentido en que Sveta es irremplazable por su yo amazónico. A pesar de que se utilice todos los mecanismos para que su voz y sus ojos azules parezcan los mismos, la asiática que la reemplazará utilizando la scalp, no alcanzará la figuración exacta de la víctima, quizá dicha imitación retorne la vida de Aluna porque el polvo ínfimo de la vida está en la cabellera, sin embargo, el ser espiritual no podrá escenificarse en público, porque la plenitud del ser amazónico y su sabiduría no se puede reemplazar con lentes de contacto o una grabadora que reproduzca la misma voz, "la multitud conmocionada ovacionará a Sveta Aluna, la líder indigenista liberada, y arrojará sobre ella paja de pino y flores de maguey. Nosotras, las del escuadrón de las ladies entonaremos el canto a la alegría con las flautas de los huesos de Rita Feind" (Vivas, 2013, p. 128).

El cuerpo de Aluna es un CSO intensivo no solo porque fue fragmentado y suprimido por la cultura dominante, sino porque también está lleno de intensidades ancestrales; es decir, las plantas ancestrales (yera, jibie y unazi) que utiliza la protagonis- ta, generan una desorganización de los órganos, de tal manera que su cuerpo adquiere un estado volátil (vuelo chamánico), el cuerpo se pierde pero el espíritu retorna para emanciparse del crimen y para vengarse de sus opresoras. Además, dichas plantas le ofrecieron la sabiduría necesaria para que Nimairango recupere sus orígenes, es allí donde el personaje se reconstituyó como legítimo ser amazónico.

La novela de Vivas, sin duda, vindica la importancia de las culturas que han sido absorbidas y vilipendiadas por las masas occidentales que ejercen hegemonía. De alguna manera, la presente obra funge como un proyecto anticolonial, porque a pesar de que Aluna fue fragmentada, el campo de inmanencia está presente en la scalp, que a lo largo de la narración significa la sabiduría amazónica, aquel conocimiento alternativo que permite construir un mundo más digno, menos individualista y mercantilista, como diría el propio autor.

\section{Referencias}

Bhabha, H. (2010). Nación y narración. Argentina: Siglo Veintiuno Editores.

Cornejo, A. (2003). Escribir en el aire. Lima: Latinoamericana Editores. 
Cornejo, A. (1984).Sobre el "neoindigenismo" y las novelas de Manuel Scorza. Revista Iberoamerica$n a,(127), 549-557$.

Deleuze, G., \& Guattari, F. (2002). Mil mesetas: capitalismo y esquizofrenia. Valencia: Pre-Textos.

Escajadillo, T. (1994). La narrativa indigenista peruana. Lima: Amaru.

González Otero, A. (2016). Definiciones y aproximaciones teóricas al género de la literatura de viajes. La Palabra, (29), 65-78.

Jiménez, J. (2014). Literatura de la incertidumbre. Revista Universidad de Antioquia, (315),, 134-135.

Lima, D. (2014). Finales para Aluna. Selnich Vivas Hurtado. Ediciones B. Bogotá, 2013. Estudios de Literatura Colombiana, (34), 183-184.

Mariátegui, C. (2007). 7 ensayos de interpretación de la realidad peruana. Caracas: Biblioteca de Ayacucho.

Marín Lara, K. (2016). Profanar cuerpos / profanar naciones. Acerca de La emancipada como novela fundacional de la literatura ecuatoriana. La Palabra, (29), 89-102.

Orrego, J. (2014). Finales para Aluna: un caso de neoindigenismo literario en Colombia. Katharsis, (17), 29-48.

Ortiz Caraballo, C.D. (2016). Los Cuícatl de Acomiztli Netzahualcóyotl: entre el ritual y la estética del pueblo Nahual. La Palabra, (29), 45-63.

Rodríguez, S. (2013). Vivas Hurtado, Selnich. Finales para Aluna. Bogotá: Ediciones B, 2013, 129 págs. Revista Lingüista y Literatura, (64),, 215-221.

Sierra Díaz, D.C. (2016). El Muntu: la diáspora del pensamiento filosófico africano en Changó, el gran putas de Manuel Zapata Olivella. La Palabra, (29), 23-44.

Uscátegui, A. (2017). Narrar la selva. Confluencias heterogéneas en la novela amazónica. Pasto: Editorial Unimar. 